Oleksandra TSYRA ${ }^{1}$, Maksym SANDULENKO $^{2}$

Opiekun naukowy: Nataliia PUNCHENKO ${ }^{3}$

DOI: https://doi.org/10.53052/9788366249844.23

\title{
MEGA SCIENCE - METROLOGIA JAKO SPOSÓB ZWIĘKSZENIA BEZPIECZEŃSTWA NAWIGACJI
}

\begin{abstract}
Streszczenie: Artykuł przedstawia główne przyczyny pojawienia się niepewności w danych wyjściowych do rozwiązywania problemów probabilistycznych żeglugi, zawiera uzasadnienie teoretyczne koncepcji błędów nienormalnych. Pokazano, jakie niepewności (błędy) wpływają na końcowe wyniki rozwiązywania problemów bezpieczeństwa żeglugi. „Pan” lub „,artefakt”. Oddzielnie w aspekcie współczesnych warunków nawigacyjnych podano pojęcie „błędu w pomiarach parametrów nawigacyjnych”. Przedstawiono krótką analizę pochodzenia błędów sprzętowych i osobistych. Cechy instrumentalnych błędów brutto takich jak możliwość długiej obecności w wynikach pomiarów parametru nawigacyjnego. Praca zawiera linki do źródeł wyjaśniających prezentowany materiał.
\end{abstract}

Słowa kluczowe: bezpieczeństwo nawigacji, wskaźniki, bezpieczna odległość, błąd, chybienie, zagrożenie nawigacyjne.

\section{SCIENCE - METROLOGY AS A MEANS OF INCREASING THE NAVIGATIONAL SAFETY}

Summary: This article presents the main reasons for the emergence of uncertainties in the initial data for solving probabilistic problems of shipping, contains a theoretical substantiation of the concept of abnormal errors. This work shows what uncertainties (errors) affect the results of solving problems of navigation safety. "Blunder" or "artifact". Separately, the concept of "error in the measurements of navigation parameters" is given in the aspect of modern navigation conditions. A brief analysis of the origin of hardware and personal errors is shown. Features of instrumental gross errors, such as the possibility of long-term presence in the measurement results of the navigation parameter. The work contains links to sources that clarify the presented material.

Keywords: navigation safety of navigation, indicators, safe distance, error, blunder, navigation hazard.

\footnotetext{
${ }^{1}$ Assoc. Professor Ph.D., State University of Intellectual Technologies and Communications, aleksandra.tsyra@gmail.com

${ }^{2}$ Student, Odesa National Maritime University, sandulenkomax0@gmail.com

${ }^{3}$ Assoc. Professor PhD., Odesa State Environmental University, the department of information technology, iioonn24@rambler.ru
} 


\section{Introduction}

Improving the safety of navigation remains one of the urgent problems at the present time, as in the time of Peter the Great, despite the equipping of ships with complex technical navigation systems and the introduction of e-navigation, the main factor of trouble-free navigation is nothing more than the professionalism of the navigator, his preparation for the analysis of navigation information and environment, that is, the human factor.

In connection with the above, the navigational safety in a broad sense can be defined as a complex characteristic of navigation, which enables ships to navigate without threat (in navigational terms) to the life of people and the integrity of ships. The decoding of this definition is seen as a complex thoughtful subject of discussion, which can be solved by joint efforts of government organizations, hydrographic services, joint work of manufacturers of maritime aids to navigation and users of these means.

Among the problems associated with the analysis of the issued and received information, on the basis of which decisions on navigation safety are made, developers of complex technical navigation systems and users need to be aware of navigation errors and methods of processing navigation information.

\section{Navigational safety criteria}

To solve the problems of navigation, a complex technical navigation system must provide the ability to connect various information sensors: heading indicators; lags; echo sounder, radar and ARPA; receivers; VHF AIS transponder.

The interest in the problem of providing the possibility of connecting sensors is due to the quality of technical parameters of the information sensors in navigation is assessed by navigation characteristics. Boat masters impose requirements on the developers of information sensors so that technical characteristics such as coverage, resolution, accuracy, reliability, noise immunity, duration of one measurement and frequency of measurements correspond to the requirements of the present time. Next, it is determined what each of the characteristics means. The coverage area is determined by the minimum and maximum measured value. Resolution is understood as a certain minimum value of the increment of the measured parameter, which can still be measured by the device. Also, the resolution of several measuring devices can be calculated through the permissible relative error of the device. Accuracy is a characteristic of the errors allowed when measuring. The generally accepted criterion of accuracy in navigation is the value of $95 \%$ of the parameter measurement error (with a confidence level of 0.95). Reliability is understood as the ability of the equipment to perform its tasks within a certain period. The reliability of the equipment is characterized by the probability of failure-free operation, MTBF and other characteristics. Interference immunity refers to the device's ability to maintain its navigation characteristics in the presence of various interference.

The duration of one measurement (determination) is the time interval from the moment of the beginning of the navigation measurement parameter until the moment the measurement result is issued. When such time is short, measurements are called instantaneous. The measurement (determination) frequency is characterized by the 
time interval between two successive measurements of the navigation parameter. When this frequency is high enough, measurements are considered continuous.

Ensuring the navigational safety is based on assessing the accuracy of the vessel's navigation, which can be characterized by the indicators of the accuracy of the navigation parameters and the location of the vessel. The indicators of the accuracy of navigation parameters consist of such concepts as: the total root-mean-square error of the navigation parameter - the square root of the sum of the squares of the rootmean-square error of all random and randomized residual or not excluded systematic components of the error of the navigation parameter; upper confidence limit for the total root mean square error estimate. Signs of the ship's position accuracy are such concepts as: root-mean-square ellipse of errors, for mathematicians a tensor is a figure of errors centered at the point of the ship's location, characterized by the root-meansquare error, acting in the direction of the major and minor orthogonal semiaxes, respectively, and the direction of the major semiaxis relative to the meridian; radial root mean square error is the radius of the circle of errors described around the point of the ship's location. Linear root-mean-square error in the generation of coordinates (latitude and longitude) of the observed or numbered position of the vessel, and the mean square rectangle of errors built on them, the center of which coincides with the point of the location of the vessel, and the semiaxes are equal to the root-mean-square error of latitude and longitude. Probability of hitting the point of the vessel's location in the rms error rectangle. The limiting rectangle of errors is a rectangle whose semiaxes are equal to double or triple semiaxes. The probability of the point of the actual location of the vessel falling into the limiting error rectangle, which depends on the distribution laws of latitude and longitude errors. The most important indicators of the statistical characteristics of water currents are the root-mean-square value of the modulus of the current velocity vector; the second initial moment of the modulus of the current velocity vector. The correlation interval of the random function of currents, which is - the time interval between measurements of the current velocity vector, at which the measurement results are considered independent, the autocorrelation function of the current velocity components along the axes of the geographic coordinate system.

The main calculation of the navigation safety is carried out when preparing a vessel for a voyage. At the same time, it is at the forefront that the ability to navigate is the possibility that estimates of the accuracy of coordinates, course, and speed of the vessel; the results of solving navigation problems are correct, effective and of high quality. Correctness is determined by the fact that this do not contain errors [1]. The following computational problems of navigation safety are considered:

assessment of the safety of the movement route or a given line of the path of the vessel and the possibilities of ensuring safety in specific navigation conditions; correction of the route or the specified track line, if necessary; justification of the vessel's maneuver with verification of its safety; assessment of the state and degree of provision of the navigation safety. Assessment of the navigational safety of the route, track, area in which the vessel maneuvers, consists in checking:

the sufficiency of the removal of these elements from hazardous areas of navigation hazard; 
the presence of sufficient depth under the keel along the route of movement and along a given line of the vessel's track, considering its actual draft and subsidence in shallow water and due to sea (ocean) waves.

Correction of a route or a track line consists in establishing their sufficient distance from the navigation hazard zones. A sufficient distance of the ship's track from the navigation hazard is characterized by the minimum permissible (safe) distance, at which a safe passage is ensured (without touching the warning line or entering the dangerous navigation hazard zone) with a probability not lower than the specified one $[2]$.

Another source on which navigation safety depends is the accuracy of the speed information used to determine the parameters of the technical means stabilization: three components of the instantaneous speed of movement and two - relative to the ground in the geographic coordinate system.

The accuracy of the assessment of navigation safety depends on errors such as instrumental and its main elements and methodological, as well as sources of error of navigation parameters [3], total root mean square error, marginal error of navigation accidents, correlation interval, type and parameters of autocorrelation function, correlation coefficient, form of the distribution law of the error of navigation accidents.

\section{Assessment of navigational incidents of shipping}

The main criterion for the optimality of navigation is safety, which can be provided by the accuracy of various measurements of navigation parameters. In the practice of navigation, the measurement result is often based on the knowledge of the navigator of the current navigation conditions, dynamics, and the use of the principle: "such a measurement result cannot exist, since it cannot exist under the current navigation conditions". This principle does not override the statistical processing of results. By its origin, the navigator does not know the essence of navigation measurements. That is, it does not know the general set of errors and its characteristics, but at the same time it is there and is of a virtual nature. Even if the navigator itself makes measurements with the help of measuring equipment, in other words, it carries out a series of observations. Or it uses measurements processed by sophisticated technical navigation systems. Regardless of the volume of the measurement series, the volume tends to infinity. In a series of measurements, there is always an unfavorable influence of gross errors that cannot be attributed to random ones due to the mechanism of their formation. This are called misses, outliers, attacks, making decisions based on such results, leads to disastrous consequences. Such errors for discrepancy with navigational hazard are subdivided into directly visible and visually unobservable. The reasons for their occurrence are the boat master's error when taking the readout or recording it, ergonomic imperfection of measuring instruments, imperfection of the measurement technique, sudden or short-term changes in measurement conditions, failure in the measuring circuit of a technical device. This are unpredictable and cannot be predicted by the methods of probability theory and mathematical statistics. Since their origin can be influenced by the human factor and artificial intelligence, such a term is appropriate here, which is more attributed to medicine, as an artifact. An artifact (from Lat. Artefactum - artificially made) is a phenomenon, process, 
object, property of an object or process, the appearance of which under observed conditions for natural reasons is impossible or unlikely. The appearance of an artifact, therefore, is a sign of purposeful interference in the observed process, or the presence of some unaccounted-for factors, as well as artificially introduced interference [4]. The terms " blunder", "throw", "lunge" can be considered synonymous. But the term "artifact" has adjusted, these four terms are similar in nature, but not synonymous. An artifact is a kind of abnormal and unusually large errors that are a direct threat to the safety of navigation, and research work towards eliminating the threat remains relevant not only in medicine, but also in shipping.

An anomaly in radio transmission of data with noise immunity (FFSS, ADT, GSM, CDMA, etc.), electronic warfare, both by classical means and by the latest technical means, developed based on the use original principles of the phase-frequency theory of measurement and conversion of radio signals [5], are understood values in several measurement results that differ significantly in amplitude and their statistical properties from other values in the series. The need to identify anomalies may arise in the following cases:

during the operation of transceiving communication devices, both terrestrial longdistance and space;

when evaluating the noise immunity of algorithms and signal processing circuits in modeling systems;

when measuring atmospheric characteristics [6].

A slip and an outlier are an element of a set of values that is incompatible with the rest of the elements of a given set.

In seamanship, a gross error is taken under a miss. The error in which the numerical value is greater than a certain maximum permissible for a certain calculation $[7,8]$. At the same time, if [7] the main reason for the occurrence of a blunder is the inattention and inexperience of observers and calculators, then the artifact [8] also includes failures of the equipment used.

In navigation, any dimension is excluded, during statistical processing, which is different from the others, regardless of the nature of its occurrence. Hence it follows that only those measurements where gross errors appear due to the human factor should be considered an error.

Such a conclusion suggests itself, a mistake in navigation measurements is recognized as a measurement, a result which for these conditions differs sharply from the rest of the measurement results of this series and with a high degree of probability does not belong to this series, as well as the result of such a measurement itself, which contains a gross error, which is called abnormal error.

The term abnormal errors are understood to be those errors for which the distribution law differs from the distribution law of a given series of errors. But it must be emphasized that this term is used only at the stage of testing the navigation system or when investigating errors. Practically several errors are worked out in the process of high-level filtration. But even this process does not make it possible to identify the form of the distribution law. Hence it follows that we mean unusually large errors in comparison with the a priori values of the observation errors, as well as for several values of the navigation parameter, which we see in the filtering process.

The sources of origin of gross errors are divided into hardware and personal. Hardware errors occur in the navigation system in the process of measuring the navigation parameter, in the process of information processing under the influence of external or 
unusually increased internal interference, malfunctions, undetected changes in the operating conditions of the navigation system, as well as due to natural emissions of errors beyond the set level that occur at random intervals. Sometimes gross errors of this kind are associated with a violation of the information reliability of the navigation system. A feature of instrumental gross errors is the possibility of their long-term presence in the results of measurements of the navigation parameter. This increases the role of methods for detecting such errors using redundant information. $[9,10,11]$. Personal gross errors occur when manually solving and interpreting the results of manual and automatic solution of navigation problems. The likelihood of gross personal errors in the process of manual solution of navigation tasks depends on the complexity of the task, psychophysiological characteristics, and the degree of fatigue of the navigator [12].

To identify gross instrumental errors of a complex technical navigation system, it is recommended to analyze the discrepancy and discrepancies in the gyrocompass and magnetic compass heading, speed and distance traveled along the log and the number of propeller revolutions in accordance with the requirements. Mistakes of the navigator when controlling the movement of the vessel and maneuvers in narrow areas are one of the main causes of navigational accidents. For the most part, these errors appear as a loss of control over the ship's position, an erroneous course assignment or errors at the moment of the beginning of the maneuver. After analyzing this kind of errors, two conditions should be considered - navigation in equipped narrows with good visibility, and - in conditions of poor visibility and/or in unequipped narrows. The first option provides the safe movement of the vessel by visual control. The second option is to maintain a navigation plot on a map, tablet. One of the ways to reduce the number of errors in the control of the movement of the vessel along a given movement trajectory in the second variant of sailing conditions is to choose a rational frequency for assessing the situation and circumstances of sailing [9].

\section{Conclusions}

The article theoretically considers the main reasons for the appearance of uncertainties in the initial components for solving probabilistic problems of shipping. From constant and random not only shipping suffers, but also a decrease in the efficiency of navigation and hydrographic support of shipping. What is said about the consistency and reliability of navigation can be reduced to the notion that in modern conditions the real accuracy of navigation and the quality of solving navigation problems are many times worse than expected. When considering the cumulative effect of persistent uncertainties on navigation efficiency: inadequacy of the law of distribution of errors, random nature of the mean square error, the possible degree of discrepancy with the actual accuracy of the navigation system the concept of "abnormal error (blunder or artifact) in navigation measurements" is theoretically substantiated, its definition is included, the need to consider errors or artifact when processing the results of navigation measurements is shown. 


\section{REFERENCES}

1. PUNCHENKO N.A., TSYRA O.V.: The strategy of informative redundancy of necessary measurements in the ship navigation as the independent direction in the development of a high-tech park. IEEE 5th International Conference on Methods and Systems of Navigation and Motion Control (MSNMC). Kyiv, 16-18 October 2018, $110-113$.

2. MIKHAL'SKIY V.A., KUSHNAREV A.G.: Problems of assessment of indicators navigation safety of ships. Software products and systems. - 2016. № 1 (113), 51 - 55 .

3. GUSHCHA I.A.: Characteristic of errors in the navigation complex systems producing fast information. Bulletin of the State University of Maritime and River Fleet named after Admiral S.O. Makarov. - 2015. - № 2 (30), 12 - 16. DOI: $10.21821 / 2309-5180-2015-7-2-12-16$.

4. Artifacts [Electronic resource]. Access mode: http://nauki-online.ru/artefakty

5. TROTSYSHYN I., SHOKOTKO G., oth.: New Technologies and Precision Measuring Transformations Radiosignals and the Perspectives of Use of their use for Systems of Control with safe Literal Appliances (UAVs). 2018 International Scientific-Practical Conference on Problems of Infocommunications Science and Technology, PIC S and T. Proceeding. - 2019, $685-690$.

6. SHERSTOBITOV A.I., MARCHUK V.I., VORONIN V.V., TOKAREVA S.V. Method for detecting abnormal measurements without evaluating the trend function and the device that implements it: US Pat. 2302655 Russian Federation.

7. KOZHUKHOV V.P., GRIGORIEV V.V., LUKIN S.M.: Mathematical foundations of navigation: textbook. M.: Transport, 1987, 208.

8. KOZHUKHOV V.P., ZHUKHLIN A.M.: Mathematical foundations of navigation: textbook. M.: Transport, 1993, 200.

9. GOST 11.002-73. Rules for assessing the abnormality of observation results. M.: Goskomstat, 1975, 18.

10. DMITRIEV S.P., KOLESOV N.V., OSIPOV A.V.: Information reliability, control, and diagnostics of information systems. SPb.: SSC RF TsNIII "Elektropribor", 2003, 206.

11. MIKHAL'SKIY V.A.: Optimal using of means of locating and computing. L.: VSOK VMF, 1985, 315.

12. MIKHAL'SKIY V.A.: Best practices and techniques for maritime navigation. L.: VSOK VMF, 1996, 244. 
